\title{
STUDIES ON THE MECHANISM OF NIDATION
}

\author{
XXI. VIABILITY OF BLASTOCYSTS IN ERGOCORNINE-TREATED \\ PREGNANT RATS
}

\section{PUTTIPONGSE VARAVUDHI* AND BERTHA L. LOBEL $\dagger$ \\ Biodynamics Institute, Weizmann Institute of Science, Rehovoth, Israel}

(Received 30th Fune 1965)

\begin{abstract}
Summary. Ergocornine methanesulphonate, in doses which are effective in inhibiting decidualization and nidation, exercised no direct toxic effect on the blastocysts of pregnant rats in which experimental delayed nidation had been induced by hypophysectomy.
\end{abstract}

The antifertility effect of a number of compounds (clomiphene, MER-25) has been correlated to a direct toxic effect of these drugs on fertilized ova (Nelson, Davidson \& Wada, 1963). However, certain ergot alkaloids have been shown to interfere with the process of decidualization and to interrupt pregnancy (Shelesnyak, 1955) and it has been postulated that these drugs reduce the available progesterone (Shelesnyak, 1954; Zeilmaker \& Carlsen, 1962; Kraicer \& Shelesnyak, 1964). Exogenous progesterone given to ergot-treated animals reversed the effects of the drug; decidualization and nidation were supported and pregnancy maintained. No study has yet been made to find out whether these drugs exert any direct action on the blastocysts. This investigation was designed to test the viability of the blastocysts following the administration of ergocornine to pregnant rats during the period of nidation but before actual attachment or implantation of the blastocysts. In normal pregnant rats, it is not possible to test the effect of ergocornine on unimplanted blastocysts during the progestational period because, when given at this time, the pregnancy is interrupted. However, such an investigation could be carried out in animals in which a state of delayed nidation had been induced. Therefore, the experimental conditions chosen were those in which survival of blastocysts was demonstrated: delayed nidation was induced by hypophysectomy on $\mathrm{L}_{2}$ or $L_{3}$, and ovariectomy was performed on $L_{6}$ or $L_{9}$.

Female rats from the Biodynamics Institute colony, exhibiting regular 4- or 5-day cycles, were used. They were caged with males of proven fertility and insemination verified by the finding of spermatozoa in the vaginal smear. This day was designated as Day 0 of pregnancy $\left(\mathrm{L}_{0}\right)$ and the days following as $L_{1}, L_{2}$, etc. Thirty-five pregnant rats were hypophysectomized on $L_{2}$ or $L_{3}$; of

* Simon B. Caulker Fellow. † Population Council Fellow, 1963-65. 
these the twelve experimental animals received a single injection of ergocornine methanesulphonate, $1 \mathrm{mg}$ in $0.25 \mathrm{ml} 40 \%$ ethanol, on $\mathrm{L}_{4}$ or $\mathrm{L}_{5}$. The twentythree controls received the vehicle only. All animals were ovariectomized on $\mathrm{L}_{6}$ or $\mathrm{L}_{9}$ and received a single injection of oestradiol benzoate $0 \cdot 1 \mu \mathrm{g}$ in $0 \cdot 1$ $\mathrm{ml}$ peanut oil, on $\mathrm{L}_{9}$. Progesterone, $4 \mathrm{mg}$ daily, was given from $\mathrm{L}_{9}$ to $\mathrm{L}_{12}$. Autopsies were performed on $\mathrm{L}_{13}$ and the uteri removed and examined for implantation sites. Treatment schedules and results are given in Table 1 . The blastocysts of pregnant rats hypophysectomized on $\mathrm{L}_{2}$ or $\mathrm{L}_{3}$ remained alive in the reproductive tract, but did not implant at the normal time. Hypophysectomy on $\mathrm{L}_{2}$ or $\mathrm{L}_{3}$ in pregnant rats thus produces a state of delayed nidation and the blastocysts may be induced to implant (as in delayed nidation produced by other means) by administration of a single dose of oestrogen and continuous progesterone. The administration of ergocornine on $L_{4}$ or $L_{5}$ did

TABLE 1

EFFECT OF ERGOGORNINE ON UNIMPLANTED BLASTOCYSTS DURING EXPERIMENTALLY INDUCED DELAYED NIDATION

\begin{tabular}{c|c|c|c|c}
\hline \multicolumn{3}{|c|}{ Treatment } & \multicolumn{2}{c}{ Autopsy $\left(L_{13}\right)$} \\
\hline Hypox. & Ovariect. & Ergocornine* & $\begin{array}{c}\text { Delayed nidation } \\
\text { total } \uparrow\end{array}$ & $\begin{array}{c}\text { Implants } \\
\text { uterus (range) }\end{array}$ \\
\hline $\mathrm{L}_{2} \ddagger$ & $\mathrm{L}_{6}$ & $+\left(\mathrm{L}_{5}\right)$ & $5 / 7$ & $4(1-8)$ \\
$\mathrm{L}_{2}$ & $\mathrm{~L}_{6}$ & $+\left(\mathrm{L}_{4}\right)$ & $12 / 14$ & $4(1-9)$ \\
$\mathrm{L}_{3}$ & $\mathrm{~L}_{9}$ & - & $4 / 5$ & $5(1-10)$ \\
$\mathrm{L}_{3}$ & $\mathrm{~L}_{9}$ & - & $7 / 9$ & $6(2-9)$ \\
\hline
\end{tabular}

* Ergocornine methanesulphonate $1 \mathrm{mg}$ s.c.

$\dagger$ All animals received oestradiol benzoate $0.1 \mathrm{mg}$ on $L_{9}$ and progesterone $4 \mathrm{mg}$ daily from $\mathrm{L}_{9}$ to $\mathrm{L}_{12}$.

$\ddagger L_{0}$ is the day on which spermatozoa are found in the vaginal smear; $L_{1}, L_{2}$, etc., the days following.

not interfere with the response of the blastocysts to physiological doses of oestrogen and progesterone on $\mathrm{L}_{9}$ : that is, nidation was observed at autopsy on $\mathrm{L}_{13}$ in a high percentage of the ergocornine-treated animals (Table 1). There was no significant difference in the number of animals with implantations, nor the number of implants per uterus, between the ergocornine-treated rats and the control animals.

It is well established that ergocornine administered to pregnant rats before or during the critical nidation period interrupts gestation and brings about the appearance of oestrus and ovulation $72 \mathrm{hr}$ after its administration (Shelesnyak, 1955; Carlsen, Zeilmaker \& Shelesnyak, 1961). The primary site of action of the drug is not known. Nevertheless, it is clear that ergocornine given to pregnant rats in the progestational period initiates a series of physiological changes in the pregnant or pseudopregnant rat, brought about by its intervention at some point in the endocrine sequence constituted by the hypothalamic-hypophysial-gonadal axis. One of the secondary reactions observed as a result of this intervention is a depression in the synthesis of protein and nucleic acids in the progestational uterus. Twenty-four hours after the administration 
of the drug a drop occurred in the values of uterine protein, RNA and DNA (Tic, 1965). This drop could be prevented by the administration of progesterone. Thus, when the results of previous investigations are correlated with the findings presented in this report, it is evident that ergocornine given during the progestational period acts by producing alterations in the blastocysts' environment, while the unimplanted blastocysts themselves are not directly affected by the drug.

\section{REFERENCES}

Carlsen, R. A., Zeilmaker, G. H. \& Shelesnyak, M. C. (1961) Termination of pregnancy in the mouse by a single injection of ergocornine methanesulphonate. F. Reprod. Fertil. 2, 369.

Kraicer, P. F. \& Shelesnyak, M. C. (1964) Analysis of the responses to ergocornine an inhibitor of nidation. F. Reprod. Fertil. 8, 225.

Nelson, W. O., Davidson, O. W. \& WADA, K. (1963) Studies on interference with zygote development and implantation. Delayed Implantation. Ed. A. C. Enders. University of Chicago Press.

Shelesnyak, M. C. (1954) Ergotoxine inhibition of deciduoma formation and its reversal by progesterone. Am. F. Physiol. 179, 301.

Shelesnyak, M. G. (1955) Disturbance of hormone balance in the female rat by a single injection of ergotoxine ethanesulphonate. Am. F. Physiol. 180, 47.

Trc, L. (1965) Growth pattern of the decidualizing rat uterus: estimations of protein and nucleic acids. Ph.D. thesis, Hebrew University, Jerusalem.

Zeilmaker, G. H. \& Carlsen, R. A. (1962) Experimental studies on the effect of ergocornine methanesulphonate on the luteotrophic function of the rat pituitary gland. Acta Endocr. Copenh. 41, 321. 